\title{
STAKEHOLDERS' MAPPING AND STRATEGY FOR RESTORING PEATLAND FOREST IN WEST TANJUNG JABUNG JAMBI, INDONESIA
}

\author{
Ignatius Adi Nugroho ${ }^{1 *}$, Darwo ${ }^{2}$, and Dhany Yuniarti ${ }^{2}$ \\ ${ }^{1}$ Secretariat of Research, Development, and Innovation Agency \\ Jl. Gunung Batu No.5 Bogor, West Java 16610, Indonesia \\ ${ }^{2}$ Forest Research and Development Center, \\ Jl. Gunung Batu No.5 Bogor, West Java 16610, Indonesia
}

Received: 11 June 2020, Revised: 30 April 2021, Accepted: 30 April 2021

\begin{abstract}
STAKEHOLDERS' MAPPING AND STRATEGY FOR RESTORING PEATLAND FOREST IN WEST TANJUNG JABUNG JAMBI, INDONESIA. Peatland forests became the centre of discussions in Indonesia because 33\% of 2.4 million hectares burned in 2014. This research aims to describe the stakeholders' position and their logic in choosing a strategy for peatland forest areas. The result shows that nine stakeholders were actively involved in peatland forest restoration in West Tanjung Jabung Regency. Based on categorization, the analysis points out that all stakeholders had occupied key players' position. Further analysis using a ladder of participation criteria found two models of participation, i.e. citizen power and tokenism. However, the value of citizen power is higher than tokenism that is $56 \%$ and $44 \%$, respectively. It means that stakeholders should develop partnership and other models in citizen power criteria to reach their targets. It also means that trust is an essential variable in the relationship among stakeholders and should be developed in peatland forest restoration. The consequence of this research is that stakeholders can improve two strategies, i.e. collaborative forest management and community-based forest management.
\end{abstract}

Keywords: Collaborative, stakeholder, peatland, participation, enabling strategy

PEMETAAN PARA PIHAKDAN STRATEGI UNTUKMERESTORASI HUTANLAHAN GAMBUT DI TANJUNG JABUNG BARAT PROPINSI JAMBI, INDONESIA. Hutan rawa gambut yang terdapat di Indonesia menjadi isu besar setelah 33\% dari 2,4 juta hektar terbakar pada tabun 2014. Tujuan penelitian ini adalah untuk. memberikan gambaran mengenai posisi para pibak dan strategi logis yang dipilih oleh mereka pada kawasan butan rawa gambut. Penelitian ini menghasilkan sembilan pibak yang terlibat secara aktif pada restorasi butan rawa gambut di Kabupaten Tanjung Jabung Barat. Analisis kategorisasi yang digunakan dalam penelitian ini menunjukean babwa semua pibak yang terdapat pada area penelitian merupakan pemain kunci. Analisis lebih lanjut menggunakan kriteria tangga partisipasi menemukan bahwa ada dua model partisipasi yang digunakan oleh para pihak yaitu tokenisme dan citizen power. Nilai citizen power dibandingkan dengan tokenisme lebib tinggi yaitu $56 \%$ berbanding $44 \%$. Hal ini berarti babwa kemitraan dan model-model lain yang terdapat di dalam citizen power akan dikembangkan oleh para pibak untuk. mencapai target mereka. Hal ini juga berarti bahwa kepercayaan merupakan variabel penting dalam relasi di antara para pibak dan barus dikembangkan dalam restorasi butan rawa gambut. Konsekuensi dari penelitian ini bahwa para pibak dapat membangun dua strategi yaitu pengelolaan butan kolaboratif dan pengelolaan hutan berbasis masyarakat.

Kata kunci: Kolaborasi, para pibak, rawa gambut, partisipasi, strategi pemungkin

${ }^{*}$ Corresponding author: toekang_jamoe@yahoo.co.id 


\section{INTRODUCTION}

Peatland forest fire has occurred in Indonesia, which has been devastating for biodiversity, social welfare and economic development in seven provinces, i.e. Riau, Jambi, South Sumatera, West Kalimantan, Central Kalimantan, South Kalimantan and Papua. The fire has covered 2.4 million hectares of peatland forest and made economic losses of approximately Rp 221 Trillion; about 16.1 million USD (World Bank, 2016). Some references such as Tata and Susmianto (2016) point out that human activities are the main cause of peatland forest fires; Edwars and Heiduk (2015), Miettinen and Soo (2010) stated that people need the peatland for agriculture, concessions and plantations (Rehman, Sabiham, Sudadi, \& Anwar, 2015). The fire on peatland forest also contributes to increasing greenhouse gas emissions to the atmosphere and influence to the surrounding human ecosystem and habitats (Ramdhani, Ruhimat, Wiyono, \& Barnes, 2020; Edwars \& Heiduk, 2015; Tata, 2019).

Human burns the peatland because they need income and peatland is the only opportunity for their agricultural activities. They construct canals on peatland to drain water, and through this, peatland can be used as farmland. Human activities have caused changes in the ecosystem and habitat level (Haapalehto, Vasander, Jauhiainen, Tahvanainen, \& Kotiaho, 2010). Due to this activity, peatland will dry and become flammable in the dry season (World Bank, 2016). Fire is a severe problem in peatland forest. In 2015, peatland forests in Indonesia had big fires due to the ENSO-El Niño Southern Oscillation effect (Edwars \& Heiduk, 2015).

At the political level, President Joko Widodo was pushed by governors exposed to smoke hazards to stop the impact on their territories. Due to the evidence, the President issued Presidential Decree number 1/2016 to establish Peat Land Restoration Agency/Badan Restorasi Gambut (BRG) as a non-structural institution directly below the President's instruction. BRG has a special assignment to restore burned peatland forests in Riau, Jambi, South Sumatera, West Kalimantan, Central Kalimantan, South Kalimantan and Papua. In 2016 and 2017, BRG has declared that this institution successfully managed the target of 200 thousand hectares for restoring peatland areas each year using rewetting, replanting, and, revitalization strategy.

West Tanjung Jabung Regency is in Jambi Province, which is one of the priority peatland restoration areas. Implementing the restoration activities in this regency was compiled through cooperation between BRG and Forest Research and Development Center (FRDC) Ministry of Environment and Forestry, responsible for the paludiculture pilot project. In terms of paludiculture, FRDC constructs the pilots in

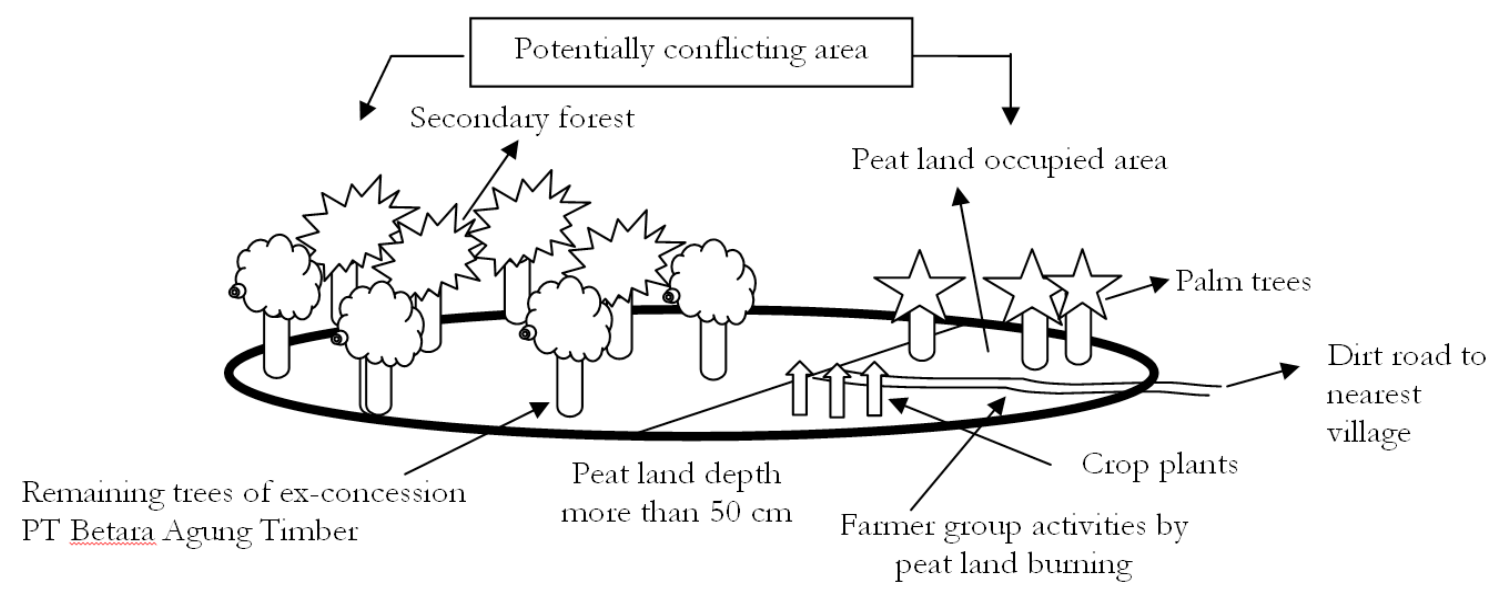

Figure 1. Current condition of Sungai Beram Hitam Forest Management Unit 
a peatland conservation area, which has been occupied by humans and is at least 5 thousand to 15 thousand hectares. Sungai Beram Hitam Forest Management Unit manages the remaining secondary forest in this peatland conservation area (FMU). Occupation activities in the peatland conservation area started in 1998 when there was a change of power in Indonesia. However, Uda, Hein, and Sumarga (2017) pointed out that the conversion of peatland forests in Indonesia has occurred between 2000-2014. Other reasons, failure and cessation of concession in that area also contributed to the human occupation when the area became an open access area. It became riskier when a migrant from another island, i.e. Java and South Sulawesi, also moved in and bought land in that area. This has occurred because local villagers, commonly chief villagers, sold that area to the migrant by the Pancung Alas system and converted secondary forest to palm oil plantation. This disorder influenced farmers in Sungai Beram Hitam Raya village to plant palm trees on peatland conservation area since the start of the occupation.

This research aims to describe the stakeholders' position and their logic in choosing peatland forest areas. Competitiveness among stakeholders may occur and involve their resources, i.e. money, opportunity, energy, and other social capitals; however, the stakeholders can also build cooperation. Nurrochmat, Nugroho, Hardjanto, Purwadianto, Maryudi, and Erbaugh (2017) concluded that stakeholders are ready to change their competitiveness to become cooperative when they found the same interest, e.g. in medicinal plants utilization in Meru Betiri National Park (MBNP). This manuscript used the conclusions of an overview of different locations in West Tanjung Jabung Jambi Province and tried to find similarities.

\section{MATERIAL AND METHOD}

\section{A. Location and Research Period}

West Tanjung Jabung Regency, Jambi Province, is about two hours travelling by car from Jambi Province capital to Kuala Tungkal as the capital of West Tanjung Jabung Regency. Figure 2 shows the research location which contains paludiculture plots. Paludiculture is how people who live near the peatland forest utilize that peatland for agriculture and rewetting and restoring its functions. Paludiculture plot is a location which is built for agriculture and plants in peatland area. This figure also shows three white colours for another use where

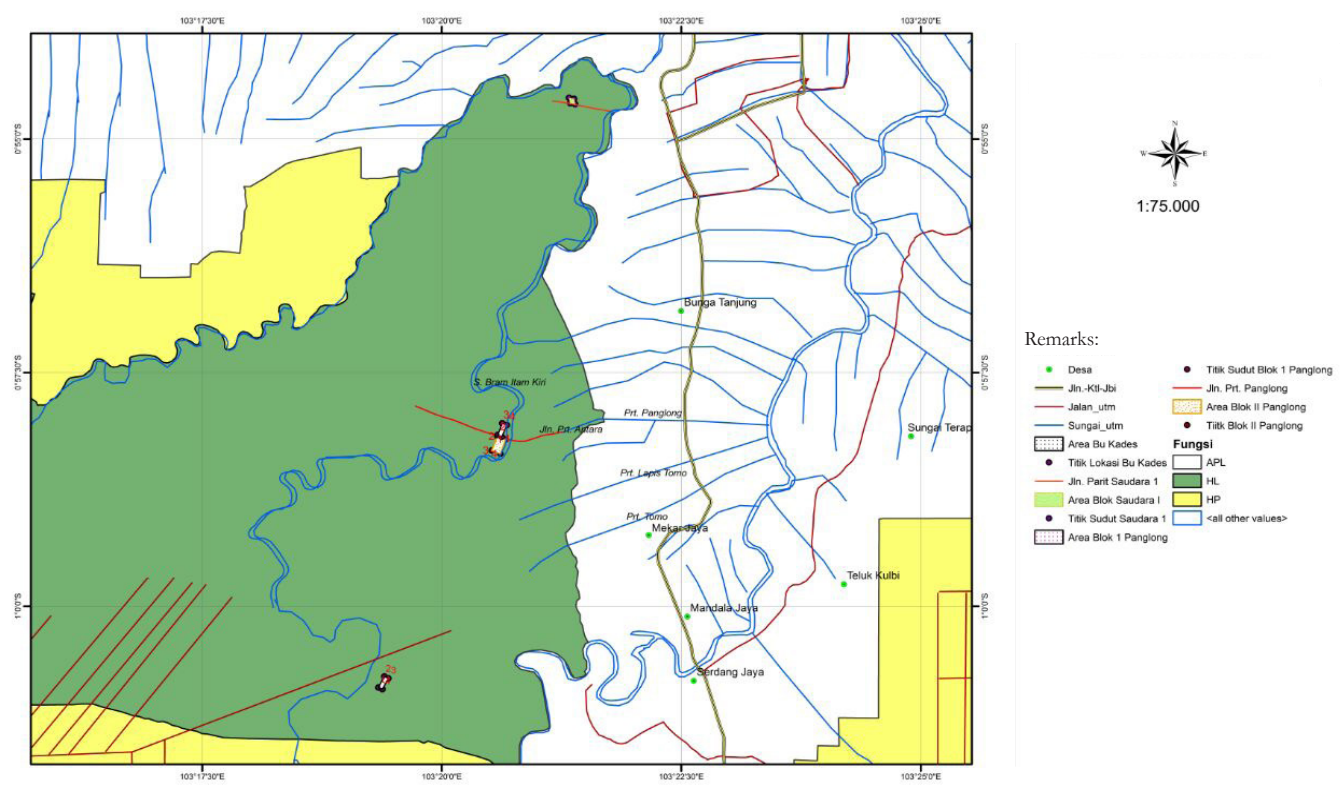

Figure 2. Location of paludiculture plots in Sungai Beram Hitam FMU 


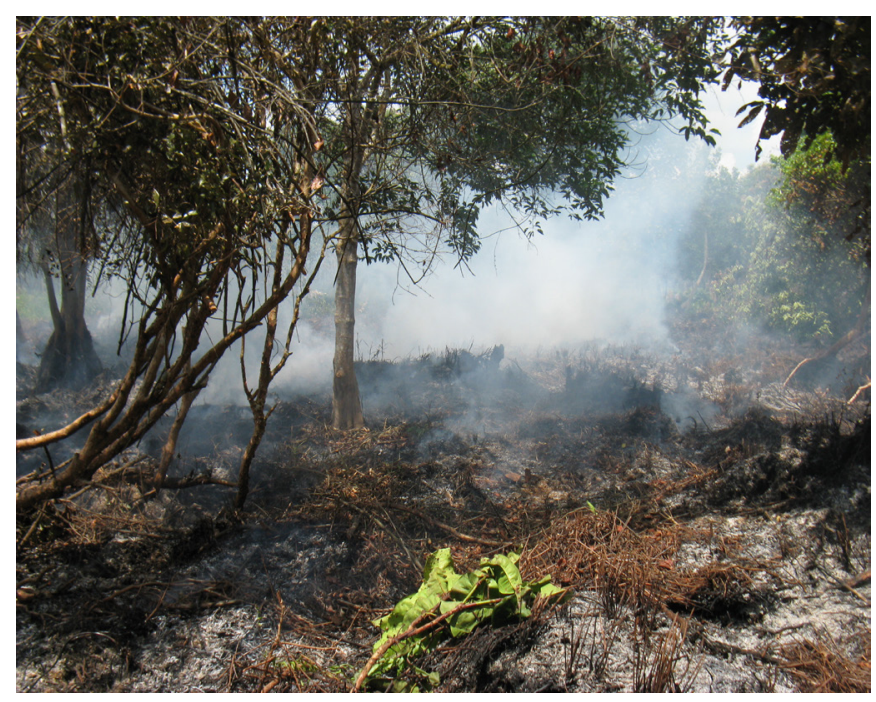

Figure 3. Peatland burning near the location of pilot paludiculture plot

the local government can use that area for any requirement, e.g. settlement, plantation, agriculture, and industry. The yellow colour is the production forest. The government can use this area only for concession and green colour is protected forest. Based on the definition, green colour is a peatland conservation forest because its position is located between Beram Hitam Kanan and Beram Hitam Kiri. Figure 1 shows that humans have built the canals (red line colour) in peatland conservation forest. This condition will worsen the peatland conservation forest, because it will degrade the water level in that area. If it occurred, peatland conservation forest would be dried and would burn easily. The consequence will be that human will occupy the peatland conservation forest and use it for agriculture. Figure 3 shows the human, near the pilot paludiculture area, uses fire to burn peatland and change it to agricultural land. This processing is used by farmers all the time because it is very efficient and effective.

This research started in June 2017 and ended in December 2017. There were three demonstration plots, and a different group owned each demonstration plot. A large amount of data have been collected, i.e. peatland soil type, forest tree species, agriculture trees, stakeholders, socio-economic, etc. However, this study describe stakeholders because it was interesting to analyze them in peatland forest conservation.

\section{B. Data Analysis}

As mentioned above, this research is using stakeholders' approaches that are essential elements in peatland restoration. Stakeholders need to be analyzed because their interest and influence have always changed over time. This research is leaning on categorization analysis which is popularized by Reed et al. (2009) and has already been tried by other researchers (Fibriani, 2012; Nugroho, 2016; Nurrochmat et al., 2017). To describe the data processing analysis, Figure 4 provides the stage plot methodology to analyze research data.

\section{Stakeholders Identification}

The definition of stakeholder is the most important in this research, because it will help the researcher recognize individuals or groups with power and interest in the peatland forest. Sometimes stakeholders are also defined as parties affected by the outcome or those who can change the result of a proposed development intervention. In the simplest term, stakeholders are always related to the interested parties. Harding and Macdonald (2001) argued that individuals or groups are interested and should be engaged in the activity. 


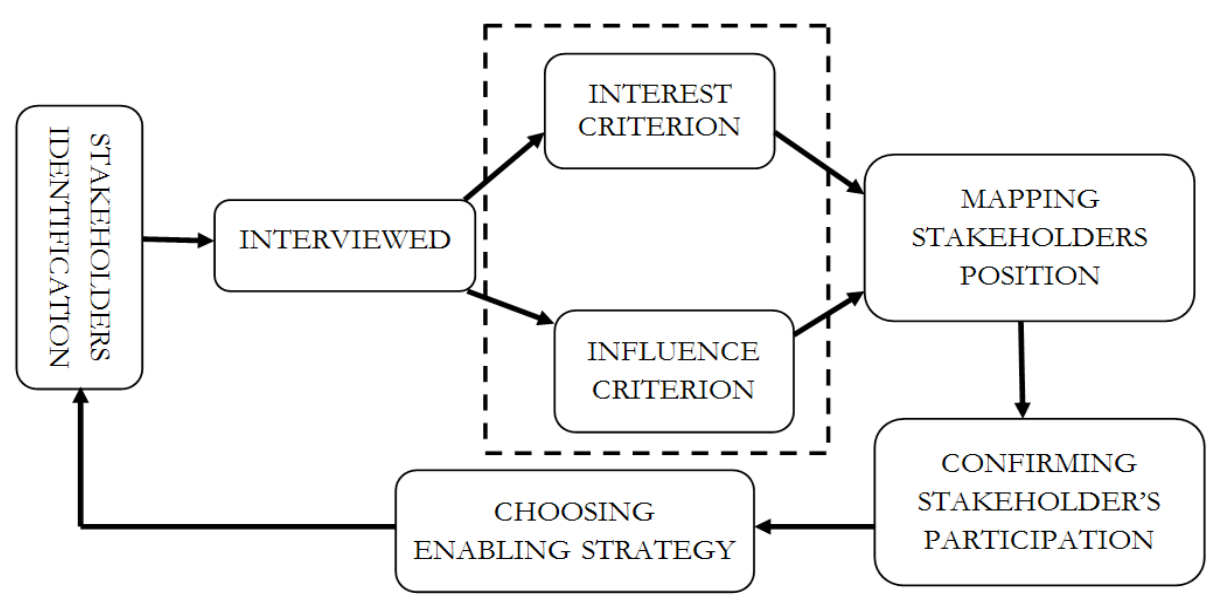

Figure 4. Data processing analysis

Sources: Modified from Reed et al. (2009); Nurrochmat, Nugroho, Hardjanto, Purwadianto, Maryudi, and Erbaugh (2017); Oktavia and Saharuddin, (2013); Azhari (2011); Collins and Ison (2006)

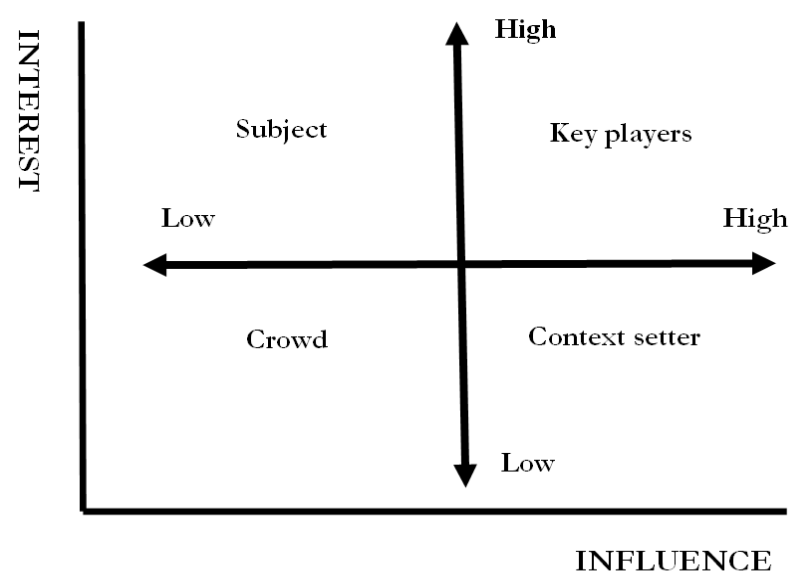

Figure 5. Matrix categorization

Source: Reed et al., (2009)

If researchers excluding them from the action, it will not make them disappear from the arena. Most literature on international development projects emphasizes the importance of those who are affected by projects to be considered key stakeholders (Mathur, Price, \& Austin, 2008). Based on the information, it can conclude that the term stakeholders always involve the interests, influence, and power of individuals or groups affected (Saputra, 2019). It is also clear that stakeholders need further analysis. Reed et al. (2009) argued that stakeholder analysis had provided a diverse range of criteria that justify the involvement of other individuals and groups.

To identify the stakeholders, stakeholder analysis was conducted accordingly (Oktavia \& Saharuddin, 2013; Reed et al., 2009). The stages of stakeholder analysis will start from (a) identification of stakeholders, (b) grouping and differing among stakeholders, and (c) investigating the correlation among stakeholders (Reed et al., 2009). The stakeholders in this research will be identified and entered into the matrix categorization based on variables of interest and influence collected by interviews. The matrix categorization is provided in Figure 5. 
To describe the matrix categorization, (Figure 5), Fibriani (2012) and Nurrochmat et al. (2017) agreed with these as stated by Reed et al. (2009) as follows:

"key players are individuals or groups who are belonging high interest and influence; subjects are individuals orgroups who are residing high importance and low importance; context setters are individuals or groups who are belonging strong influence and little interest; and crowds are individuals or groups who are belonging low importance and low importance"

\section{Interview of the Stakeholders}

In this stage, stakeholders who have been identified will be interviewed. The process will start from key stakeholders Mathur, Price, and Austin (2008) as the primary component. To get more specific information regarding stakeholders' activities in peatland forest, this study attempt to extract information from key stakeholders. It is essential because a key stakeholder in this research is a person who has a role as a key informant (Fibriani, 2012; Nugroho, 2016; Nurrochmat et al., 2017). On the other hand, this research is also leaning on a qualitative approach wherein interviews of crucial stakeholders would be successful if the persons as key informants are participating.

Interview of the key informant takes place on purposive sampling. Each key informant represents an organization such as Forest Management Unit (FMU), Farmer Groups, NGO, Traders, Politicians and Village Government. Each informant obtains the questions that correlate to the variables with interest and influence that are the dotted lines in the box in Figure 4. Fibriani (2012), Nugroho (2016), and Nurrochmat et al. (2017) argued that the interest variable contains five elements, i.e. motivation, perception, needs, supporting forms, and beneficiaries. Variables of influences also have five items, i.e. participation, role and contribution to the decision, relation to another person, human resource capacity, and financial support.

To quantify those variables of the above paragraph, such as motivation, perception, and needs, the scoring technique for each element has been developed. The scoring rank is designed from 1 to 5 , wherein each number has described the informant's answer low to a high level of importance. Fauziyah and Sanudin (2017), Budiaji (2013), Brown (2011) argued that the Likert scale is useful as a tool to describe the answering level of each participant who was interviewed. Following the Likert range, the $1^{\text {st }}$ means that the informant has the lowest answer score to the question element, the $2^{\text {nd }}$ means low score, the $3^{\text {rd }}$ means middle score, $4^{\text {th }}$ means high score and $5^{\text {th }}$ means the highest score. After all, respondents answered the questions; it was formulated the answers in tabular data. To confirm them in the position, scatter point was used in excel operational system to establish the matrix function of $\mathrm{X}$ and $\mathrm{Y}$. This stage is following the categorization analysis concept (Reed et al., 2009).

\section{Mapping Stakeholders Position}

Recognizing the stakeholders' positions is needed because it points out their power which is the correlation between interest and influence (Reed et al., 2009). Each position will be different among stakeholders depending on their answer and power perception which they have. It will also explain that the stakeholder's location is very dynamic, and each stakeholder can influence others. Relations among stakeholders and their connectivity were also observed during the interview, helping us understand the relationship among stakeholders better. Due to these reasons, mapping stakeholder's position will help us describe who is more powerful than others (Nugroho, 2016). In another case, recognizing those positions also encourage parties to develop cooperation among them as an enabling strategy in the field, such as the utilization of medicinal plants in Meru Betiri National Park, East Java Indonesia (Nurrochmat et al., 2017) and community forestry in Sarolangun Regency, Jambi Indonesia (Fibriani, 2012). This is possible because those positions will draw the occupation of each stakeholder in the critical player, subject, context setter or 
crowd. The stakeholders who are in the key player position are usually cooperative and always ready to establish cooperation among them. However, they are in a subject position against the stakeholders who are the key players. However, they should be maintaining their positions because stakeholders in a subject position always establish an alliance with others (Reed et al., 2009; 2017). In this mapping, it means that peatland restoration needs more information regarding stakeholders because this variable is influencing how human utilize that area. The stakeholders who are in key player position are recommended to be involved in peatland restoration. It is helping policymakers doing programs in that area.

Regarding this research finding, we also faced of some difficulties primarily to find stakeholder who have position in subject, context setter and crowd, even though that other position is important to mapping the stakeholder position. It's difficult because when we start this research, actors or persons who must be interviewed hard to find, remote area, and there is no public transportation at the location. Almost actors can be met at the night time after they finished work at the land field.
We realized that this research actually difficult and particularly when we should described all stakeholders to map their positions. However, all challenge is not make us give up and tried to finish this work. We know that this work is still not perfect and hope finish it at next time as long as the resources provided, particularly to fill the other position of the stakeholder (Figure 8).

\section{Confirming Stakeholder's Participation}

In this stage, we used the participation theory to analyze the stakeholders. Oktavia and Saharuddin (2013), Azhari (2011), Collins, Kevin, and Ison (2006) argued that participation has stages which are described as the correlation among parties where degrees of involvement dispersing from not engagement, tokenism and citizen power. This theory is defined as Arnstein's Participation Ladder (Figure 6).

Arnstein's Participation Ladder divided the degree of participation into eight ladders, i.e. manipulation and therapy (non-participation degrees), informing, consultation and placation (tokenism degrees), partnership, delegated power and citizen control (citizen power degrees). According to Oktavia and Saharuddin

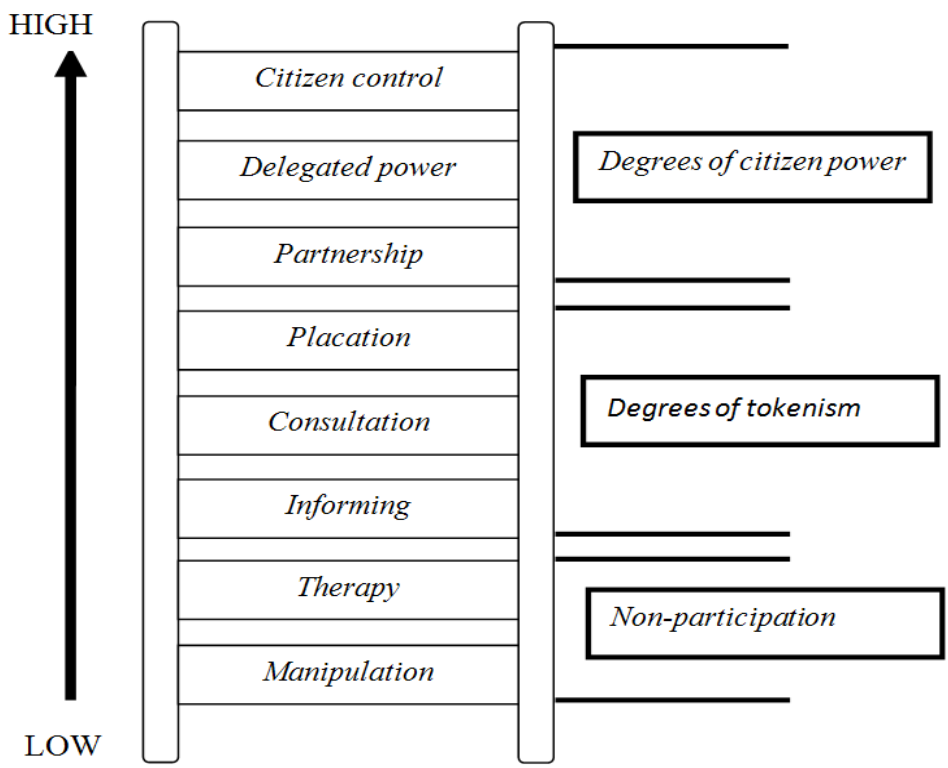

Figure 6. Ladder of participation

Sources: Oktavia and Saharuddin, (2013); Azhari (2011); Collins, Kevin, and Ison (2006) 
(2013), a small group controls participation in the public community where a small group has been positioned as elite and has the power to govern the general population. Therefore, public involvement has been supported by the elite; however elite create different programs which are opposite to public programs, which can be described as therapy. Both of these conditions point out that there is no participation among stakeholders because dominant parties control the majorities and give them limited information. They were informing means that participation is directly controlling the information to the community. The consultation also means that community participation to give their opinion have been sufficient; however, opinion has not been assured to be decided by an elite. And placation means that the public community has been empowered; however, program execution depends on the program availability of the elite. These three definitions of participation describe tokenism correlation among stakeholders where the minority could influence and force the program to powerless stakeholders.

The partnership means that both public community and elite have the same perception, responsibility, and programs and then actively developed cooperation between them on condition that the public community has the power to delegate their program by representative persons to elite and both parties doing programs based on common agreement defined as delegated power. The last citizen control means the public community can control all programs that influence their livelihood. Following these definitions, the degree of power given to the community is when the government shares the power to the public community and establishes programs together. In this way, the public community will have the same potential as the government, developing a communication strategy to aid the program and increasing public participation.

\section{Choosing Enabling Strategy}

Since the government shares its power, the public community will increase their trust in the government. Siisiainen (2000) has seen that trust is a special attribute of social capital in the organization. The social organization also can be drawn by the stakeholder structure that is present in the community. Each stakeholder has different attributes such as title, prosperity, political supporters, family or clan member, etc. Social capital is the total of all actual and potential resources associated with the possession of a lasting network of the more or less institutionalized relationship of knowing or respecting each other (Sylviani Suka, Surati, \& Kurniasari, 2020). It is expressed and institutionalized by name or title, which shows in their attributes such as family, clan, nobility, party and so forth (Siisiainen, 2000). In terms of social capital, Birner and Wittmer (2000) suggest that social capital definition correlates with political capital in which political capital also contains two private and public perspectives. In the personal perspective, political capital consists of the resources which are actors, i.e. an individual or a group, can dispose of and use to influence the policy formation process and realize outcomes that are in the actor's perceived interest (Birner \& Wittmer, 2000; Gilens \& Page, 2014). This definition corresponds to political resources as necessary resources in Hick and Misra (1993) arguments, i.e. pluralist, statist, mass political conflict and social-democratic perspectives.

On the other hand, political resources also need instrumental resources and infraresources. Instrumental resources are defined as specific resources used by specific authors to realize their perceived interests. And then infra-resources are defined as resources that broadly facilitate diverse actors pursuits of their interests by empowering their action or conditioning the effectiveness of specific instrumental resources (Hick \& Misra, 1993). To explain this concept, Winkel (2012) argued that instrumental resources respond to welfare factors that are dispersed in actors interest, such as actors who are pro or anti-welfare.

These actors usually are connected with sub-governmental administrative authority 
and tend to statist and develop administrative approaches. Actors connected with interest organization and electoral leverage tend to develop plural approaches, and other actors who develop disruptive leverage tend to political conflict approaches. Infra-resources is relevant for welfare spending to include such as state fiscal capacity and state internal organization (Hick \& Misra, 1993; Birner \& Wittmer, 2000). To develop this theory, Birner and Wittmer (2000) proposed to change the term of private perspectives into instrumental political capital. This concept was used to distinguish private term, which is often associated with the individual's position; however, in term of the actor's perspective, it is often related to the organization in the political arena concept.

Mentioning political capital, Birner and Wittmer (2000) also proposed to change the public perspective term into the structural political capital term. This concept corresponds to structural variables in the political system, which influences the possibilities of the diverse actors to accumulate instrumental political capital and condition the effectiveness of the different type of instrumental capital. The structural political capital relates to infraresources in the political resources theory (Birner \& Wittmer, 2000). Following these theories, actors can exchange their social capital into political capital through discovering their same interest, i.e. welfare (Lunenburg, 2012). It is a needed requirement that actors understood their common purpose and also have given highest participation. Then, that participation can encourage those actors to raise trust among actors so that the political capital can be the function of their interest. Democratization is required that makes actors obtain their political positions. It has the same meaning as the citizen power concept in ladder participation theory (Collins \& Ison, 2006; Azhari, 2011; Oktavia \& Saharuddin, 2013).

Regarding that situation, shifting social capital into political capital in the actor's context is one condition to help actors defining their common strategy purposes. Birner and Wittmer (2000) and Nurrochmat et al. (2017) argued that actors have an option to choose their institutional strategies to manage the natural resources excellently based on the objective condition of state capacity and social capital power. It means that actors who lived in the peatland area also have the same characteristic to manage their optimum institutional strategies.

Nurrochmat, Darusman, and Ekayani (2016) divided the strategies into four areas. Firstly, state management strategy is compatible if state capacity condition is powerful and social capital condition is weak. Secondly, the opposite

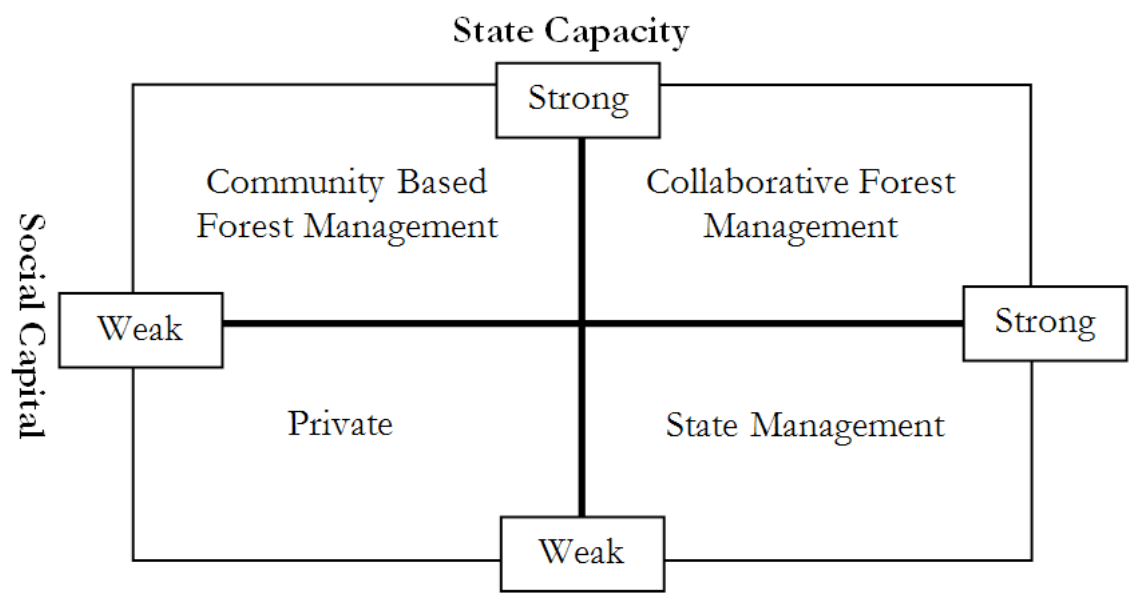

Figure 7. Strategies options related to state capacity and social capital

Sources: Nurrochmat, Darusman, and Ekayani (2016); Nurrochmat et al. (2017); Birner and Wittmer (2000) 
of state management strategy is community based forest management. This condition is compatible if state capacity is weak and social capital is powerful. Thirdly, collaborative forest management is the best strategy option because state capacity and social capital have the same powerful condition. In this condition, structural political capital and instrumental political capital have the same position and both can construct the partnership. The last strategy is opposite of collaborative forest management if state capacity and social capital have the same weak condition. It is defined under private management. In this condition, the private sector can manage natural resources by contractual systems. The condition of natural resources must constantly manage and forbidding open access to the resources. The strategies option is shown in Figure 7.

\section{RESULT AND DISCUSSION}

This research draws on stakeholders' position and their participation by mapping them on peatland utilization. The research data is shown in Table 1 below.

\section{A. Description of Each Stakeholder}

Peatland utilization involved many stakeholders in West Tanjung Jabung. Most of them utilize peatland as farmland to earn economic-financial resources and meet their families income. Nine major stakeholders are involved in peatland management, i.e. Forest and Environment Agency Jambi Province
(FEA), Forest Management Unit (FMU) of West Tanjung Jabung, politician, Middle trader juvenile fruits of Pinanga sp., industry old fruits of Pinanga sp., NGO of WARSI, Mega Buana Farmer Group (FG), Village Government of Sungai Beram Itam Raya (VG), and Forest Farmer Group (FFG). These stakeholders have been interviewed. Minor stakeholders not yet involved in the field because of some constraints to this research, i.e. remote area, lack of a public vehicle, and very bad accessibility to the location.

\section{Forest and Environment Agency Jambi Province (FEA)}

FEA is a major stakeholder who is responsible for managing FMU in Jambi Province. There are two functions of FMU, i.e. protection and production entity refer to Forest Law number 41/1999. However, there are nine FMUs in Jambi Province; namely Merangin, Tebo, Sarolangun, Kerinci, Muara Bungo, Muara Jambi, West Tanjung Jabung, East Tanjung Jabung, and Batanghari. Those FMUs were under control and managed by FEA, especially after the revision of Local Government Law number 23/2014, whereby the forest agency at the district level has been terminated. The consequence is that FEA has the dominant authority to manage the forestry sector in Jambi. Then all forestry businesses and their customers have been concentrated to the province level. The forest agency at the district level has been changed to FMU.

Table1. Data stakeholder position

\begin{tabular}{lcc}
\hline \multicolumn{1}{c}{ Stakeholders } & $\begin{array}{c}\text { Influence } \\
\text { (score) }\end{array}$ & $\begin{array}{c}\text { Interest } \\
\text { (score) }\end{array}$ \\
\hline Forest \& Environment Agency of Jambi Province & 3.4 & 3.4 \\
Forest Management Unit (FMU) of West Tanjung Jabung & 3.2 & 4.6 \\
Politician & 3.5 & 3.4 \\
Middle trader of old fruits Pinanga sp. & 4.2 & 4.0 \\
The industry of juvenile fruits Pinanga sp. & 3.6 & 3.8 \\
NGO-WARSI & 4.0 & 3.8 \\
Mega Buana Farmer Group & 3.2 & 4.2 \\
Village Government of Sungai Beram Itam Raya & 3.2 & 4.0 \\
Forest Farmer Group (FFG) & 2.8 & 3.0 \\
\hline
\end{tabular}




\section{FMU of West Tanjung Jabung}

This FMU emphasized conservation and protection functions of the peatland area based on the Minister of Environment and Forestry decree number SK.77/Menhut-II/2010/9 November 2016 and Governor's rule of Jambi Province number 1176/2017/13/10/2017. Those policies are the legal standing for FMU operations in West Tanjung Jabung Regency and have covered 15,050 hectare peatland forest area and confined to Right Beram Itam and Left Beram Itam Rivers. One-third of this peatland forest area was occupied by the local community and used for palm tree plantations. The remaining two-third is the secondary forest in this FMU. The head of FMU, mentioned that the circumstance caused by the mismanagement of the concession.

\section{Politician}

Interview of the politician has been done in Kuala Tungkal City. He was an ex-parliament member and had a good relationship with Sungai Beram Hitam Raya Village. As a politician, he also supports the local community to use the peatland forest area in FMU. By that strategy, the politician hopes the community will earn economic benefits. However, the politician believes that this FMU has been an open access area, and the community can use that forest land for other function. The consequence is that local communities occupy that FMU and encourage the local institution, namely Pancong Alas, which contributes to trading the occurrence of peat forest land.

\section{Middle Trader of Old Fruits of Pinanga} sp.

Middle Trader (MT) of old fruits Pinanga sp. is a critical stakeholder in the field. This stakeholder usually becomes an intermediate trader of pinanga's fruits between farmers and industry. They create channelling because farmers need them to sell their fruits of Pinanga sp., and from this, farmers earn direct payment for their products. In the field, there are many MTs, and at least three or four MT in every village collects fruits to the industry. Family relation sometimes determines the price; for example, a wife works in the industry, and a husband works as MT. The wife gives price information to the husband, including price change in the fabric, and by this provided data, a husband can influence farmers to set the pricing of pinanga fruits. Farmers planted Pinanga sp. because their fruits can be used as natural dye material.

\section{The Industry of Juvenile Fruits of Pinanga sp.}

This industry is also an important stakeholder which operates in the peatland field. Its existence provides many opportunities for farmers to develop the products of Pinanga sp. However, in some cases, farmers did not like to harvest the juvenile fruits of Pinanga sp., because they are worried that the fruits will be broken. The industry informed the industry that West Tanjung Jabung is a suitable area for planting Pinanga sp. For the industry itself, those fruits meet the raw material requirements for candy. This industry provides half-finished candy materials and delivers that to China after being packed.

\section{NGO-WARSI}

This stakeholder is very active because its interest in the community's livelihood, socioeconomic and opportunity for the local people involved in forestry management is very high. WARSI, the abbreviation of Warung Konservasi, has been actively engaged in social forestry programs because WARSI has developed a bridge between government and community in peatland forest to manage the forest sustainably. Further, agricultural products planted in peatland and people in that area also need farmland to meet their livelihood requirements. Then, they used burning practice to open the area to become farmland. The impact is that it has raised the hazard caused by burning peatland and haze, which has also impacted other provinces such as Riau, Jambi and South Sumatera. The central government was supported by the local government and has 
established the Peat Land Restoration Board (PLRB). The special task of this institution was to resolve and restore peatland burning area of 2.4 million hectares which have been burned in Riau, Jambi, South Sumatera, West Kalimantan, Central Kalimantan, South Kalimantan, and Papua. WARSI has responded to this situation and proposed social forestry programs as the best choice of strategy to restore peatland forest.

\section{Mega Buana Farmers Group}

This group has been an exceptional stakeholder because most people who joined this group obtained rights to the peatland area by the pancong alas system. Originally, before becoming a farmer, they worked in fisheries because most of them had originated from the Bugis ethnic group, which was familiar with fishery tradition. This group used the pancong alas rights to open peatland forest for palm tree plantations. There was also conflict between this group and the village government. The Mega Buana leader represents the members' group told to the village leader that their palm plantation area could not be planted because flood always covers their plantation land. However, at the same time, this leader still rejected the village government's program to normalize the river, which causes the flood in that area. There were different conditions between palm trees planted in the dry area and planted by this group. Because of the group leader's position, who has always rejected the village government's program, this group has been excluded from other government programs.

\section{Village Government of Sungai Beram Itam Raya}

The Village Government (VG) of Sungai Beram Itam Raya is a significant stakeholder because she/he representing the highest decision-maker at the village level. VG has a good relation to the political party actors who support VG in the head of the village election. It is very strategic for the political party actors because they can influence the decision maker's management at the village level to achieve their aims. On the other hand, the political party actors can also develop their access to natural resources in that village. In this case, the political party actors are the counterpart to the village head to make policy on peatland utilization in Beram Itam Raya Village. The village head gives them information regarding natural resources which can be extracted, and political actors give supporting financial allocation to do the programs based on that information.

\section{Forest Farmer Group (FFG)}

Most members of this group are palm oil farmers. However, there is so much complaining that palm oil plants cannot grow optimally in peatland condition. Many plants can grow until ten years, and after that, palm oil plants' productivity decreases, resulting in decreasing income for farmers. This condition resulted in that part of the farmers tried to find a solution, and by cooperating with FMU, they have designed the concept of mixed crops between palm oil and forest trees. Farmers have a high perception that this combination will raise their income in the future because forest trees have a reasonably good price in that village. FMU also supports that activity and build cooperation and allow farmers to plant peatland with mixed crops under FMU jurisdiction. Further, farmers also can get coaching programs on mixed crop plantation by FMU and then get priority information on other government programs such as seed crops, funding etc.

\section{B. Mapping Stakeholders}

Mapping of stakeholders is an important step to finding out each actor's position based on a categorization analytical approach (Reed et al., 2009). It gives us information regarding stakeholders who were disposed to build cooperation with each other and have a common perception regarding utilization program in peatland forest. This method also assists analyst to formulate programs on peatland regarding 


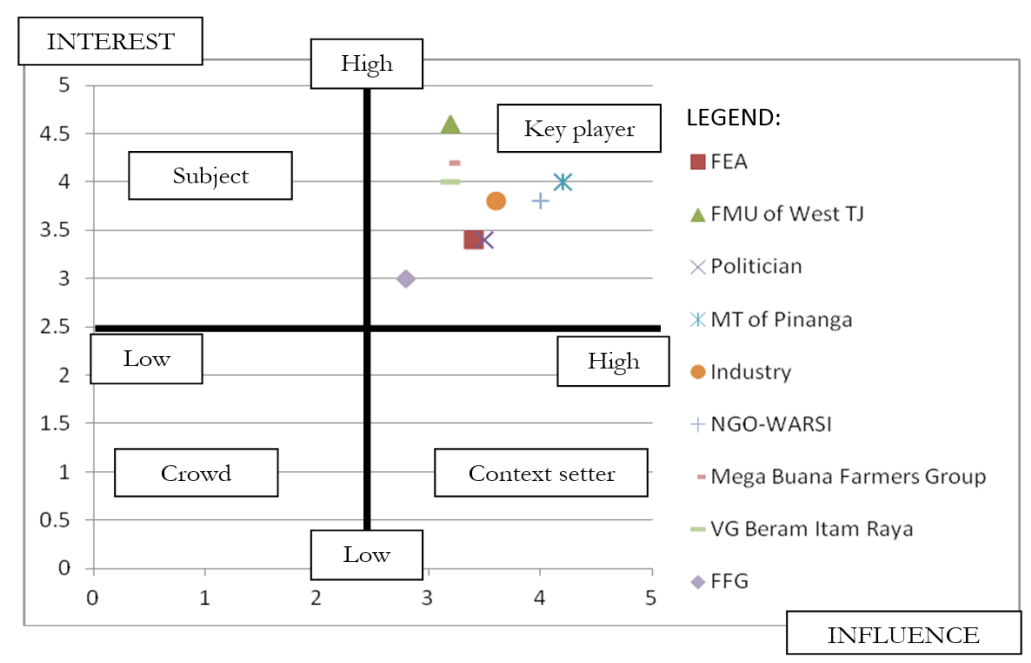

Figure 8. Mapping of stakeholders by categorization analytical method

stakeholder's interest and evaluate their level of participation in the field. Further information is shown in Figure 8.

Based on Figure 8, we know that mapping stakeholders in three other quadrant is getting empty. It's not mean that in three quadrant there is no stekaholder who contested their interest and power. In this research, authors getting difficulties to raise up the data from three quadrants because we have limitation budget, time and remote area to collect data from all stakeholder. This research is not finished and authors brave to publish the paper because there is important findings so that readers can get new perspective to the reseach. We hope other researchers disposed to fill empty quadrants.

\section{Stakeholder's Participation}

Interview of stakeholders regarding their participation level distributed between tokenism and citizen power. The value of tokenism is $44 \%$ and citizen power $56 \%$. It means that citizen power was more dominant participation in which partnership and delegation of power became the key activities (Azhari, 2011; Oktavia \& Saharuddin, 2013). Further information on this interview result is shown in Table 2.

\section{Stakeholders Mapping}

Figure 8 shows stakeholders distribution in key player positions. The analytical categorization used in this method is not connecting completely with another stakeholder in the matrix position. It means that stakeholders positioned in key players' positions have high interest and influence on peatland forest utilization. It also gives information that stakeholders involved in that field correlate with each other with dynamic features. For example, FAE and FMU are local government agencies; however, at the same time, both institutions have a different viewpoint. FEA uses a more structural approach to solve the problems related to peatland forest, and it needs a rules framework before working and consequently tends to respond slowly.

FMU is more functional because it operates and is closer to field stakeholders, and is faster to respond. However, this stakeholder does not have enough budget to work with appropriate planning. Under the new law on local government number 23/2015, FMU management is below FEA. It caused by is financial budget for FMU activities depends on the budget available to FEA management. Debates on both institutions also occurred related to effective approaches to resolving problems such as a socio-economic and burning fire in agriculture activities. FMU is often proposing direct programs supporting farmer group needs in the field; however, FEA 
Table 2. Participation degree of stakeholders

\begin{tabular}{|c|c|c|c|}
\hline Stakeholders & Major Activities & $\begin{array}{l}\text { Participation } \\
\text { Model }\end{array}$ & $\begin{array}{c}\text { Participation } \\
\text { Degree }\end{array}$ \\
\hline $\begin{array}{l}\text { Forest \& Environment Agency } \\
\text { of Jambi Province }\end{array}$ & $\begin{array}{l}\text { - Rules of law are the rationale } \\
\text { for these stakeholders to join in } \\
\text { peatland restoration } \\
\text { - Partial participation }\end{array}$ & Consultation & Tokenism \\
\hline $\begin{array}{l}\text { Forest Management Unit (FMU) } \\
\text { of West Tanjung Jabung }\end{array}$ & $\begin{array}{l}\text { - Participation of all parties is } \\
\text { an important reason to restore } \\
\text { peatland even they are faced with } \\
\text { low financial access } \\
\text { - Inviting competent parties to be } \\
\text { involved in peatland restoration } \\
\text { - Agroforestry programs are } \\
\text { bridging farmers to increase their } \\
\text { socio-economic capacity }\end{array}$ & Partnership & Citizen power \\
\hline Politician & $\begin{array}{l}\text { - Taking side in the public interest } \\
\text { and earn socio-economic capacity } \\
\text { - Supporting peatland restoration } \\
\text { based on appropriate policy }\end{array}$ & Delegated power & Citizen power \\
\hline $\begin{array}{l}\text { Middle trader of old fruits of } \\
\text { Pinanga sp. }\end{array}$ & $\begin{array}{l}\text { - Trading old fruits of pinanga with } \\
\text { industry for natural dye product } \\
\text { - Price information on old pinanga } \\
\text { raw material was obtained from } \\
\text { family members }\end{array}$ & Informing & Tokenism \\
\hline $\begin{array}{l}\text { The industry of juvenile fruits } \\
\text { of Pinanga sp. }\end{array}$ & $\begin{array}{l}\text { - Socialization on this business to } \\
\text { local government such as raw } \\
\text { material needs, sources and so on } \\
\text { - The industry using these natural } \\
\text { materials for candy }\end{array}$ & Informing & Tokenism \\
\hline NGO-WARSI & $\begin{array}{l}\text { - Supporting farmers interest to } \\
\text { have access to peatland forest } \\
\text { and managing social forestry } \\
\text { programs }\end{array}$ & Partnership & Citizen power \\
\hline Mega Buana Farmer Group & $\begin{array}{l}\text { - Utilization of peatland forest } \\
\text { was influenced by pancong alas } \\
\text { institution } \\
\text { - Clan members encouraged them } \\
\text { to occupy peatland forest }\end{array}$ & Informing & Tokenism \\
\hline $\begin{array}{l}\text { Village Government of Sungai } \\
\text { Beram Itam Raya }\end{array}$ & $\begin{array}{l}\text { - Takes side in village community's } \\
\text { interest to utilize peatland natural } \\
\text { resources } \\
\text { - Develops innovation to increase } \\
\text { village economics }\end{array}$ & Delegated power & Citizen Power \\
\hline Forest Farmer Group (FFG) & $\begin{array}{l}\text { - Develops palm trees in peatland } \\
\text { forest, however ready to build } \\
\text { cooperation to other parties with } \\
\text { the condition it can increase their } \\
\text { economic capability } \\
\text { - Supporting the agroforestry } \\
\text { system to exchange palm trees }\end{array}$ & Partnership & Citizen Power \\
\hline $\begin{array}{l}\text { Scoring for Tokenism and } \\
\text { Citizen Power is } 4(44 \%) \text { and } \\
5(56 \%)\end{array}$ & & & \\
\hline
\end{tabular}


is more often focusing on the law aspects than direct programs. This condition creates a gap and needs to be resolved to restore peatland forest in West Tanjung Jabung Regency.

This figure also shows that Mega Buana Farmer Group has the opposite position to Village Government, FMU, and FFG. It occurred because Mega Buana Farmer Group believes that the peatland area they managed was their property rights under the pancong alas institution. They always defend that area because they have spent money to buy it through the previous village head in 1998. Pancong alas is an illegal institution because historically, forest land encroached by farmer group has been originally the concession of PT Betara Agung Timber based on Director General of Forestry number SK 19/kpts-1/1977 dated on 1 January 1977. The total forest land which was managed was $260.350 \mathrm{Ha}$. After the concession permit expired, this forest land has been taken by PT Wira Karya Sakti (PT WKS) based on the Minister of Forestry decree number SK 381/ Menhut-II/1997 dated 4 April 1997 to avoid open access to that area. On $15^{\text {th }}$ June 1999 , the Government of Jambi Province determined that the forest land will become protection peatland forest based on the decree of Jambi Governor number 108/1997.

Further, this decision has been strengthened by the Minister of Forestry and Plantation decree number $421 / \mathrm{kpts}-\mathrm{II} / 1999$. From 2007 2009 conflict occurred between the community and the Forest Agency of West Tanjung Jabung Regency. The community did not agree that the protection of peatland forest, which they managed, became state property land. To overcome it, the parliament of West Tanjung Jabung set up mediation between the community and Forest Agency. Both parties agreed that the peatland forest is state property land; however, the community was given access to manage that land in two planting periods. Although this conflict was over, the problems related to peatland forest encroached by farmer groups were still unfinished because the pancong alas system has not truly ended. Certain persons who have power still do that system commonly in scatters by leasing to other farmers. It has become a sensitive issue, and local government's programs are always rejected in that location.

This conflict shows that open access situation has occurred in which farmer groups could encroach the peatland forest. There were ten years of a vacuum of management in that peatland forest, and this situation encouraged farmers to occupy the peatland (Okereke, 2019; Handoyo, 2015). Hackett (2001) has described open access situation as res nullius where there is no owner, and all people have the liberty to use that natural resource. Then, no one has the right to exclude anyone else in that peatland forest which they managed. It is the rationale that people who are nearest to the peatland forest have the opportunity to use the natural resources. Regarding that, Ribot and Peluso (2003) argued that access is not expressing the property rights such as goods and bundling of power that people can use to occupy natural resources such as market, capital, technology, labour, authority, and social identity and so on.

The community in Sungai Beram Itam Raya has known that the chief of Mega Buana Farmer Group is an opponent person. In this situation, analytical categorization should be the entrance to the chief in the subject position; however, in this research, his position changed to become a key player. It means that the opponent person on the cooperation side depends on his interest and how the proponent can develop an approach. We facilitated the opponent to be involved in the programs, such as agriculture mixed with forest planting and pasture system and used Mangifera indica, Nephelium lapaceum, Pinanga sp., goats, and Shorea balangeran, and so on which were planted in the peatland area. Their purpose is to involve Mega Buana Farmer Group to become a partner in this program because they can influence other farmers disturbing peatland forest, which FMU managed.

Another stakeholder who was analyzed is the private sector. This stakeholder was represented by the industry and middle traders interested in 
juvenile and old pinanga fruits. Farmers have planted pinanga and Coffea liberica, which were used for saving function. It was essential for them because palm trees cannot give income continuously. Sometimes, palm trees are decreasing in productivity, and it will influence farmer's ability to support family needs such as paying tuition fee for children, hospital costs and so on. Under that condition, pinanga and Coffea liberica give additional income for farmers.

The existence of private sectors in that field is essential because they have acted as buyers of agriculture products. Furthermore, private sectors are also playing a balancing act between the agricultural market and supply chain of the products which can take place. Consequently, many middle traders of pinanga fruits because the industry cannot stand alone to buy the fruits directly from farmers. It would make it more costly and requires much time if the industry is attempted to absorb those products alone without cooperation with middle traders.

On the other hand, middle traders have benefits because they have established a network with farmers and developed co-partnership to sell pinanga fruits. It has created a value chain for trading pinanga fruits in the peatland area. Some cases harm industry, middle traders, and farmers; they also create a lower benefit for farmers than if they sell those products directly to the industry. Middle traders are accused of being rent-seekers for those products without counting that middle traders maintain the market's mechanism, the economic system in that area. When middle traders are removed from that system, the farmers will experience disadvantages because they lose access to cash. It was a difficult position for the farmers' group because they were in the lowest position in the value chain market. This problem should be broken, and the government should facilitate farmer groups to access the pricing of their agriculture products. It proposes the government to create an open pricing system of agriculture products by social media or internet devices.

Figure 8 shows thatFMU, Mega Buana farmer group, middle traders, and Village Government has close relation with FMU, which is the highest. Together, those stakeholders are very important because they work and represent socio-economic and ecological activities in which the government is interested in restoring the peatland forest. Without socio and economic aspects, stakeholders such as farmers group and middle traders will risk developing their products, which means that peatland forest will be extracted and agricultural land will be extended. It is difficult for the government because they should engage other stakeholders to participate in peatland forest restoration. In our opinion, it is essential using analytical categorization for mapping the positions of stakeholders and the well-known essential stakeholders who will manage the peatland restoration programs.

\section{E. Stakeholders Participation}

The stakeholder's participation is an important variable because it shows how interaction is happening among stakeholders involved in the peatland forest restoration program and how they developed cooperation, relation, and decision-making processes. Table 2 describes the two-degree stakeholders' participation model in the field, i.e. tokenism and citizen power. Citizen power has a higher degree than tokenism, with 56\% and $44 \%$ values for each model. Those values indicate that citizen power has more influence for the stakeholder to participate in peatland restoration. Based on our interviews, restoration programs such as mixed crop plantation, livestock, and local forest species are very interesting for stakeholders. It gives them a new perspective that palm plantation is not the only plantation to earn income in peatland. There are other alternative forms for mixed crops to develop income while being involved in peatland restoration programs. Figure 2 also describes how stakeholders already participate in those areas. The black points show the GPS coordinates, which have been taken to mark and build mixed crop demonstration plots. There 
were three demonstration plots, and different groups owned each demonstration plot.

The stakeholder's participation was an increase when restoration programs were rolled out and developed in those areas. The establishment of demonstration plots has been a marker that participation moves forward. Several ideas offered to the stakeholders got a positive response because it allows increasing their income. For example, in those plots, we have designed mixed plants among fruits, plantation, and forest species. Fruit species are used for seasons, i.e. Nephelium lappaceum, Durio zibethinus, and Mangifera indica. Plantation species usually used were Coffea liberica and Pinanga sp., and the others for forest species used Dyera costulata, Shorea balangeran, and Illex cymosa. This condition is also similar to that people are getting incentives, they tend to be involved in the rehabilitation programs (Murniati \& Suharti S, 2018; Watts, Tacconi, Hapsari, Irawan, Sloan, \& Widiastono, 2019).

The positive response from stakeholders to the programs can be viewed as an opportunity to participate in peatland restoration. However, Table 2 also describes that tokenism still gives $44 \%$ of which stakeholders have chosen. It means that specific stakeholders doubt that peat swamp restoration activities will be successful. It is marked by their perception of peat swamps products only as products that can be harvested regardless of their sustainability. This is an inhibiting factor for peat swamp restoration activities, so there is a need for a unique strategy to develop peatland restoration in the field. When we started this research, the local institution of peatland restoration was not firmly established, so the consequence was that there was no financing operation for that institution in 2017.

Figure 7 describes how stakeholders can develop a strategy concept regarding natural resources restoration. Birner and Wittmer (2000) proposed that social capital owned by stakeholders can be transformed into political capital. Such changes can determine the strategic approach that stakeholders can take. In this regard, Nurrochmat et al. (2017); Nurrochmat, Darusman, and Ekayani (2016); Santika et al. (2017); Nurrochmat (2017) and Birner and Wittmer (2000) used an approach that of links between state capacity and social capital to analyze suitable strategies that stakeholders can use in activities related to natural resources. Figure 8 and Table 2 show stakeholder's participation linked to viable strategy related to social capital and state capacity. Then, it could be concluded that peatland restoration strategy

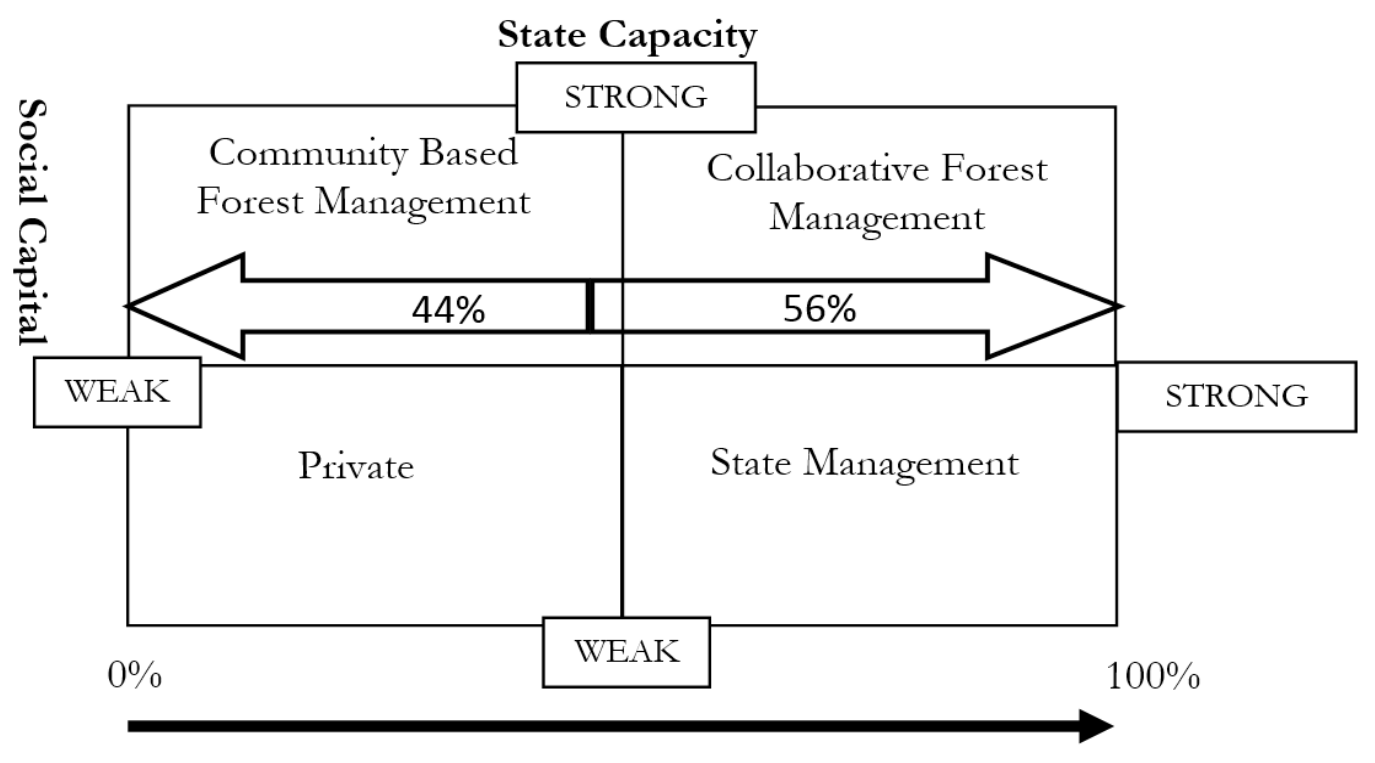

Figure 9. Strategy process from CBFM to CFM related stakeholder 
at the research site is in the process leading from Community Based Forest Management (CBFM) to Collaborative Forest Management (CFM). The weakness of state capacity in peatland forest is very easily controlled or accessed by stakeholders where it also involves payments to actors who are not representing the interests of the state. This transaction cost must be decreased because it disturbs the participation process of the stakeholders in the field. The strategy process from CBFM to CFM related stakeholder participation is shown in Figure 9.

Figure 9 shows two strategy models that can be developed regarding stakeholders participation, i.e. CBFM and CFM. These two strategies take place in the field, especially CBFM, because stakeholders' acceptance of those is adequate. To encourage participation in those, strengthening government personnel is very important in the peatland restoration program in the field. Because of this training personnel, opening market and technology and capital access has been an obligation for stakeholders involved and intended to develop peatland forest restoration activities. This also argues that similar collaborative action needs attention from all stakeholders (Axelsson, Angelstam, Elbakidze, \& Stryamets, 2011; Desmiwati \& Christian, 2019).

To increase state capacity after the peatland burning in 2014-2016 government strengthened their powers and supported the local government. Policies related to peat land restoration has been released in 2016 and 2017 when the restoration program was launched. BRG has allocated fund in that year of approximately Rp 152 billion to restore peatland by community involvement on the site in seven provinces in Indonesia. The programs have also been announced at COP-23 in Bonn and received positive responses from the participants. Further, the document of BRG strategic planning 2016-2020 said that BRG needs Rp 10.5 Trillion budget to restore peatland in seven provinces for which the sources of the budget would come from national and/or local government funds, donors, investors, private sectors and NGOs (Badan Restorasi Gambut, 2016). This condition can describe why stakeholder's participation tends to increase in the citizen power position (Table 2), and stakeholders have been in the position of being crucial players (Figure 8). Political changes in government and governance have encouraged participation on the site.

One of the weaknesses of this position, strategy and participation, is the government's position. Government policy indeed influenced stakeholders to participate in peatland restoration in the field. However, this condition cannot survive if the government fails to manage its capital and establish an institution regarding peatland restoration at the site. This should be clear because people tend to use fire to utilize the peatland for agriculture. Yulianto, Soekmadi, Hikmat, and Kusmana (2019) described that the existence of local institutions guarantees the local people to involve resources because there is clarity of the boundaries and legitimacy for them.

On the other hand, participation also encourages people to involve restoration if they have the opportunity by the government policy, i.e. social forestry programs (Tata \& Tampubolon, 2016). People can build village forest, and in the period 2012 to 2016, this village forest area tends to expand in Sumatra and Kalimantan (Santika et al., 2017). By this argument, the participants will be completed if government policy meets people's desire who utilize the resources in the field (Muttaqin, Alviya, Lugina, Almuhayat, Hamdani \& Indartik, 2019).

\section{CONCLUSION}

This research concludes that stakeholders mapping could help decision-makers define a suitable strategy using the stakeholder participation approach. Identifying their interests and influence and participation can develop stakeholders' strategies to maintain the peatland forest restoration area. In this research, we provide two strategy models 
that are collaborative forest management and community-based forest management. Collaborative forest management strategy is used if stakeholders have high participation and consider their opportunity to access the peatland forest area and how the government supports the stakeholders to do the peatland restoration. Another strategy, community-based forest management, is also considering access; however, the government still has scepticism to support stakeholders because there is a need for clarification regarding budgeting, institutions, and so on to restore the peatland forest.

\section{ACKNOWLEDGEMENT}

This research was conducted based on a corporation agreement between Forest Research and Development Center and Peat Land Restoration Agency (BRG), located in West Tanjung Jabung, Jambi Province. Authors are grateful to the Director-General of Peat Land Restoration Agency for their funding support and the Director-General of Research and Innovation Agency to support the researchers to be done.

Authors also say special gratitude to Professor Mark S. Reed from Scotland's Rural College for his professional review to this paper. We hope this result can be utilized by the policy makers to give the best decision on the field. Each researcher contributes to this manuscript such as researcher number one is a team member and has contributed to analyzing actor activities on research field. The researcher number two is a team leader and has contributed to steer the overall research and focused on forest culture activities. And the researcher number three has contributed to reaching socio-economic data on the field.

\section{REFERENCES}

Axelsson R., Angelstam P., Elbakidze M., \& Stryamets N.E.J.K. (2011). Sustainable development and sustainability: Landscape approach as a practical interpretation of principles and implementation concepts. Journal of Landscape Ecology, 4, 5-30.

Azhari K.I. (2011). Tingkat partisipasi masyarakat pada tahap perencanaan dalam program neighbourbood development: Studi kasus Desa Jendi Kecamatan Selogiri Kabupaten Wonogiri. Fakultas Teknik Universitas Sebelas Maret, Surakarta.

Badan Restorasi Gambut. (2016). Rencana strategis Badan Restorasi Gambut 2016-2020. Badan Restorasi Gambut Republik Indonesia.

Birner R., \& Wittmer H. (2000). Converting social capital into political capital: How do lcal communities gain political influence? A theoretical approach and empirical evidence from Thailand and Columbia. Paper submitted to the $8^{\text {th }}$ Biennial Conference of the International Association for Goettingen.

Brown J.D. (2011). Likert items and scales of measurement? SHIKEN: JALT testing \& evaluation. SIG Newsleter, 15(1), 10-14.

Budiaji, W. (2013). Skala pengukuran dan jumlah respon skala likert. Jurnal Ilmu Pertanian dan Perikanan, 2(2), 127-133. Retrieved from http://umbidharma.org/jipp on the $1^{\text {st }}$ December 2020.

Collins K., \& Ison, R. (2006). Dare we jump off Arnstein's ledder? Social learning as a new policy paradigm. In Proceedings of PATH (Participatory Approaches in Science and Technology) Conference. Edinburgh.

Desmiwati, \& Christian F.Y. (2019). Levelling up the collaborative forest management in Indonesia: A review. IOP Publishing.

Edwars S.A., \& Heiduk F. (2015). Hazy days: Forest fires and politics of environmental security in Indonesia. Journal of Current Southeast Asian Affairs, 34, 65-94.

Fauziyah, E., \& Sanudin, S. (2017). Efektifitas kelembagaan dan kebijakan hutan rakyat di Kabupaten Banjarnegara dan Banyumas. Jurnal Wasian, 4(2), 79-88.

Fibriani D. (2012). Evaluasi proses implementasi kebijakan butan rakyat di Kabupaten Sarolangun, Jambi. Sekolah Pasca Sarjana, IPB, Bogor.

Gilens M., \& Page, B.I. (2014). Testing theories of American politics: Elites, interest groups, and average citizens. American Political Science Association, 12, 564-581. doi: //10.1017/ S1537592714001595. 
Haapalehto T., Vasander H., Jauhiainen S., Tahvanainen T., \& Kotiaho, J.S. (2010). The effect of peatland restoration on water table depth, elemental concentration and vegetation: 10 Years of Change. Restoration Ecology, 19(5), 587-598.

Hackett S.C. (2001). Environmental and natural resources economics: Theory, policy and the sustainable society $\left(2^{\text {nd }}\right.$ Ed.). New York: M.E.Sharpe.

Handoyo. (2015). Resolusi konflik TN Tesso Nilo: Tinjauan relasi pemangku kepentingan dengan power stakeholder analysis. Jurnal Analisis Kebijakan Kebutanan, 12(2), 89-103. doi://10.20886/jakk.2015.12..89-104.

Harding L., \& Macdonald C. (2001). Developing new approaches for stakeholder engagement in the minerals sector, mining, minerals and sustainable development project, IIEED. London.

Hick A,J., \& Misra. (1993). Political resources and the growth of welfare in affluent capitalist democrasies, 1960-1982. American Journal of Sociology, 99(3), 668-710.

Lunenburg, F.C. (2012). Power and leadership: An influence process. Intenational Journal of Management, Business and Administration, 15, $1-8$.

Mathur V.N., Price A.D.F., \& Austin, S.A. (2008). Conceptualizing stakeholder engagement in the context of sustainability and its assessment. Construction Management and Economics, 26(6), 601-609.

Miettinen J., \& Soo, C.L. (2010). Status of peatland degradation and development in Sumatera and Kalimantan. AMBIO A Journal of the Human Environment, 39, 394-401. doi://10.1007/ s13280-010-0051-2.

Murniati, \& Suharti S. (2018). Toward zero burning peatland preparation: Incentives schemes and stakeholders roles. Biodiversitas, 19, 1396-1405.

Muttaqin M.Z., Alviya I., Lugina, M., Almuhayat F., Hamdani U., \& Indartik. (2019). Developing community-based forest ecocsystem service management to reduce emission from deforestation and forest degradation. Forest Policy and Economics, 108, 1-9.

Nugroho I.A. (2016). Pemetaan para pibak dalam pemanfaatan tumbuhan obat sebagai bahan baku jamu: Studi kasus di Pulau Jawa. Sekolah Pasca Sarjana IPB. Bogor.
Nurrochmat D.R. (2017). Strategi kebijakan pembangunan kehutanan dan lingkungan berkelanjutan (Orasi). Bogor: IPB.

Nurrochmat D.R., Nugroho I.A., Hardjanto, Purwadianto A., Maryudi A., \& Erbaugh, J.T. (2017). Shifting contestation into cooperation: Strategy to incorporate different interest of actors in medicinal plants in Meru Betiri National Park, Indonesia. Forest Policy and Economics, 83, 162-68.

Nurrochmat D.R., Darusman D.R., \& Ekayani M. (2016). Kebijakan pembangunan kehutanan dan lingkungan: Teori dan implementasi. Bogor.: IPB Press.

Nurrochmat, D.R., Nugroho, I.A., Hardjanto, Purwadianto, A., Maryudi, A., \& Erbaugh, J.T. (2017). Shifting contestation into cooperation: Strategy to incorporate different interest of actors in medicinal plants in Meru Betiri National Park, Indonesia. Forest Policy and Economics, 83, 162-168. doi://10.1016/j. forpol.2017.08.005.

Okereke, C.D.I. (2019). Palm oil, power and participation: The political ecology of social impact assessment. Environment and Planning E: Nature and Space, 1-21. Retrieved from http://sro.sussex.ac.uk/id/eprint/86366/ on the $1^{\text {st }}$ December 2020.

Oktavia S., \& Saharuddin. (2013). The relationship between role of the stakeholder and community participation in agropolitan program in Karacak Village, Leuwiliang Subdistrict, Bogor District. Solidity: Jurnal Sosiologi Pedesaan, 1(3), 231-246.

Ramdhani M.R., Ruhimat, A., Wiyono, \& Barnes, A. (2020). Imaging tropical peatland and auifer potential in South Sumatera using electrical resistivity tomography. Indonesian Journal of Forestry Research, 7(1), 1-14.

Reed M.S., Grave A., Dandy N., Posthumus H., Huback K., Morris J., ... Stringer, L. C. (2009). Who's in and why? A typology of stakeholder analysis methods for natural resources management. Journal of Environmental Management, 90, 1933-1949.

Reed M.S., Vella S., Challies E., de Vente J., Frewer L,., Hohenwallner-Ries D., ... van Delden, H. (2017). A theory of participation: What makes stakeholder and public engagement in environmental management work? Restoration Ecology, 26(S1),1-18. doi://10.1111/rec.12541. 
Rehman S.A.U., Sabiham S., Sudadi U., \& Anwar, S. (2015). Impacts of oil palm plantations on climate change: A review of peat swamp forests' conversion in Indonesia. International Journal of Plant and Soil Science, 4, 1-7.

Ribot J.S., \& Peluso, N. L. (2003). Theory of access. The Rural Sociology, 68(2), 153-181.

Santika T., Meijaard E., Budiharta S., Law E.A., Kusworo A., Hutabarat J.A., ... Stigner, M. (2017). Community forest management in Indonesia: Avoided deforestation in the context of anthropogenic and climate complexities. Global Environment Change, 46, 60-71.

Saputra, E. (2019). Beyond fires and deforestation: Tackling land subsidence in peat land areas, A case study from Riau, Indonesia. Land, 8, $1-24$.

Siisiainen M. (2000). Two concepts of social capital: Bourdieu vs. Putnam. Finland.

Sylviani, Suka, A.P., Surati, \& Kurniasari, D. P. (2020). Social capital in managing community plantation forest: A case study at $\mathrm{KPH}$ Boalemo, Gorontalo Province. Indonesian Journal of Forestry Research, 7(1), 71-82. doi://10.20886/ijfr.2020.7.1.71-82.

Tata H.L., \& Susmianto, A. (2016). Prospek paludikultur ekosistem gambut Indonesia. Bogor: Forda Press.

Tata, H.L., \& Tampubolon, A. (2016). Participatory approach in the peat swamp forest management of two different forest statuses in Central Kalimantan, Indonesia. In $15^{\text {th }}$ International Peat Congress 2016: Peatlands in Harmony Agriculture, Industry and Nature (pp. 582 - 586). Kuching-Serawak, Malaysia.
Tata, H. L. (2019). Mix farming systems on peat land in Jambi and Central Kalimantan Provinces, Indonesia: Should they be described as paludiculture? Mires and Peat, 25, 1-17. doi://10.19189/MaP.2018.KHR.360.

Uda S. K., Hein L., \& Sumarga, E. (2017). Toward sustainable management of Indonesia tropical peat lands. Wetlands Ecology Management, 25, 683-701.

Watts J. D., Tacconi L., Hapsari N., Irawan S., Sloan S, \& Widiastono, T. (2019). Incentivizing compliance: Evaluating the effectiveness of targeted village incentives for reducing burning in Indonesia. Forest Policy and Economics, 108, 1-15.

Winkel, G. (2012). Foucaults in the forests-A review of the use of "Foucauldian" concepts in the forest analysis. Forest Policy and Economics, 16, 81-92.

World Bank. (2016). The world bank annual report 2016. Washington DC. doi: //10.1596/978-14648-852-4.

Yulianto, S. R., Hikmat A., \& Kusmana, C. (2019). Crafting local institution using socialecological system framework for sustainable rattan governance in Lore Lindu National Park. Jurnal Manajemen Hutan Tropika, 25, 135145. 